\title{
Revisiting Women Empowerment: A Review Of Policies On Landuse And Food Security In Zimbabwe.
}

\author{
Munyaradzi A. Dzvimbo \\ Department of Development Studies, \\ Lupane State University, P.O. Box 170, Lupane, Zimbabwe \\ Monica Monga \\ Department of Development Studies, \\ Lupane State University, P.O. Box 170, Lupane, Zimbabwe
}

Tinashe M. Mashizha

Community Capacity Building Initiative Centre for Africa (CCBICA), RTG Centre, Harare-Bulawayo Highway, Kadoma, Zimbabwe.com

\begin{abstract}
The Land question in Zimbabwe and most countries of the Global South has always been marred by the injustices perpetrated by the colonial governments in the equitable distribution of land. Women have been severely disadvantaged yet they are the ones who contribute so much in agricultural production and food security. Thus, land tenure, ownership, food security and access are interlinked, directly and indirectly. This paper seeks to explore while revisiting policies that have addressed land-use, tenure security and ownership in relation with women in Zimbabwe. Women have always been a domineering force in agriculture in which they contribute immensely though their contributions has not been fairly chronicled and publicised. Thus land is a key resource to empowering women in the socio- economic growth trajectory and poverty alleviation. Successful realisation entails a functioning transparent land administration system. Hence, access to arable and productive land is vital to most women who live in the communal areas and depend wholly on farming for their livelihoods. It is in this realm that, land plays a significant part and as a socio-economic catalyst, policies inclined should clearly state the position of women as far as ownership is concerned. Various statutory and legal statutes should address rights of women so that they will be able to continue contributing to food security. In light of these objections, this paper further examines and explores current and also already researched literature on empowering women in the lenses of land-use, right, access and their contributions to food security.
\end{abstract}

Key words: Agriculture, Food Security, Land, Rights, Tenure

\section{INTRODUCTION}

The Land question in Zimbabwe and most countries of the Global South has always been marred by the injustices perpetrated by the colonial governments in the equitable distribution of land. It is in this realm, that secure land tenure creates incentives for women farmers to invest labour and resources in their farmers over long term and adopting new technologies and sustainable land management practices. The debate on land and women's ownership in rural Africa is a bone of contention which has been there and is actually at the centre of scholarly literature written by scholars and academics from other places. As one of the foremost, natural resources and an economic catalyst, land is central to the existence and livelihood of human kind. Both traditional and contemporary societies have used and exploited 
land for a several reasons (Abdul and Aritwi, 2005; Zamchiya, 2011). It is imperative to note that, Africa is a continent where most of its rural settlements still use land based on traditional or customary land tenure systems instead of modern tenure systems established by state institutions. It is in this context, that it appears to be a common practice especially in rural communities of sub Saharan Africa. Land is critical and forms the engine for women empowerment, mainly because it is the main source of livelihood, secondly it is a source of power and lastly it identifies it-self while people living on it (Mafeje, 2003; Moyo, 2004; Cotula, 2009). Women population in most countries of the Global South is more than that of men leaving them with much for contributing immensely to rural and economic development (Buka, 2002; World Bank, 2006). It is a fact that women in most countries of Global South play a pivotal role in agricultural production and farming where they mostly make up the majority of the agricultural workforce. Presently, more and more women are heading rural households and gender is actually a basic determinant of social relations and rights in households as well as in communities. In Zimbabwe women constitutes about 52\% of the total population. Furthermore, class, ethnicity and caste also determines an individual's opportunities, access of and to resources, aspirations, standard of living, status in the community, and self-perception. In addition, women's ability and rights to resources influence their ability to produce and their ability as producers (Moyana, 2002; FAO, 2007; Odeny, 2013). Murisa (2010) as supported by Hungwe (2011) posits that secure access to productive land is of paramount importance to millions of marginalised people living in the rural areas whole solely depend on agriculture, livestock or forests for their livelihood. This however, reduces their vulnerability to starvation and poverty whilst influencing their ability to invest in their productive activities and in the sustainable harnessing of their resources, enhances their prospects for better livelihoods and helps them develop more equitable rapport and relations with the majority of the society while contributing to justice, peace and sustainable development (Chiweshe, 2002; IFAD, 2010).

\section{A Theory of Modification: Gendered Analysis of Edifice and Action}

It is vitally to understand what is meant by women empowerment and also to understand what is meant by power. Power can be intellectualised in terms of people's capacity to make strategic life choices and exercise influence. Empowerment hence refers to the processes by which this capability is acquired by those who have been hitherto denied it. People who exercise a great deal of choice in their lives to the extent of imposing their choices on others may be very dominant and powerful, but they are not empowered in the sense in which the term is used here because they were not disempowered in the first place. Our theory and concept of change therefore narrates and relates to change in power relations. It rests on the intertwined and tangled philosophies of structure, the institutionalised (and hence often invisible) constraints and constrictions on human action that give rise to durable and robust forms of inequality, and action, the role of human actors and their efforts to reproduce or replicate, modify or transform structural inequality.

\section{METHODOLOGY}

This study makes inferences based on intensive literature review of current discourse, topical issues, published and unpublished materials.

\section{DISCUSSION AND RESULTS HISTORICAL BACKGROUND}

Land issues have dominated the discourses and practices of development in postindependence Africa. Hence, the primary goal of land reform in Zimbabwe has been to redistribute land to black people. Most of the discourses on land have paid scant regard to the internal social stratification of the colonized peoples especially with respect to land entitlement (Mkandawire, 2012). Concerns over equity of access across age, class and gender 
differentiation have been relegated to the background while issues to do with commercial viability, efficiency of land-use and the effects of tenure on productivity have enjoyed much attention (Richardson, 2005; Rosset and Courville, 2006). Throughout the various phases of evolution, land reform in Zimbabwe aimed at redistributing land to black people and the number of women beneficiaries has been very low in comparison to that of men (World Bank, 2003; Human Rights Watch, 2004; De Grassi, 2008).

The disparities in the composition of the beneficiaries of various land reform programs is a result of policy-makers" continued promotion of the productivity of the poor by targeting men, yet women have historically managed and shouldered the responsibilities of domestic labour, family care and nutritional security (World Bank, 2008) despite the presence of over 35\% women headed and women-managed households nationally (Alexander, 2006; UN, 2010). Compared to men, women have weaker property rights and tenure security and despite this awareness, there still is no defined mechanism that is structured to ensure that women acquire secure tenure (FAO, 2011). Land reform strategies in Zimbabwe have incorporated processes of exclusion, worsening social divisions and class disparities (Bernstein, 2012). Land reforms continue to apply inheritance and land allocation rules that discriminate against women such that single, married, divorced and widowed women are particularly vulnerable to losing the land upon death of the man in whom the land is registered (Bryceson, 1996; Moyo and Yeros, 2005). Historically, women have comprised the bulk of family, contract, seasonal and casual labour in Zimbabwe. The majority of the labourers in agriculture before and after land reform are women yet they rarely control the land (Arrighi et al., 2010). Land reform has actually been shown to marginalize women and reduce their commitment to agriculture (Giffe et al., 2011; Mkandawire, 2012).

\section{Women and Land Management}

The technical systems and structure of land policy need to be holistic and inclusive of women predicament and ownership right (Moyo and Yeros, 2005; Cousins, 2009; Kindi, 2010). Thus, it provides fulfilling opportunities for ensuring that rule of law and policies on equality in access are implemented or that informal agreements on access to land are formalized and thereby improve tenure security. In Zimbabwe, women have been recognised through their immense contribution to agriculture and rural development. Hence, they were able to be allocated smaller farms with total sizes ranging from 50-100ha during the land redistribution exercise (Moyana, 2002; Moyo and Sukume, 2004). In systems of private tenure rights, land titling and registration is a prerequisite for land owners to use their land as collateral. Processes of land redistribution, ownership and registration of tenure have to be transport so that it does not discriminate against women but encourages an increase in women's access to land (Logo and Bikie, 2003; World Bank, 2009). The informal systems of land administration and management operate is corrupt, marginalises and disadvantages women's participation in land auditing and management particularly difficult (Odeny, 2013). It is therefore imperative to assess whether principles of gender equity are broadly embraced, socially or legally accepted, and promoted at the institutional level so as to assess the gender balance within land administration and management agencies; and evaluating the rules, institutions, and players involved in customary, religious, and informal frameworks -particularly those regarding inheritance and divorce (ibid).

\section{Women's Security and Tenure}

While countries of the Global South have achieved different legal and policy strides in addressing the land issue, studies have shown that even where laws are equitable, women may not know their legal rights. Furthermore, implementation may still be gender-biased, and law enforcement may be grossly inadequate or prejudiced against women. It is vital to examine and 
explore legislations in countries of the Global South that affect women's land tenure rights with a specific reference to the types of rights that exist and how those rights are held including whether women can hold property in their own names (Odeny, 2013). Some countries of the Global South have positive action oriented provisions in their legislation; however implementation remains a major challenge (Logo and Bikie, 2003; FAO, 2007; Mkandawire, 2012).

The legal framework on access to land by women does not guarantee them security of tenure. In Zimbabwe, most cases women have access to land through male heads of households such as husbands, fathers or brothers (UN-Habitat, 2002; Doss, 2006; Zamchiya, 2011). This dependence on males actually makes their use of the land dependant on their continuation of their relationship with these men. Thus, there are situations where men who work and live in urban areas have control of agricultural produce produced by their wives and children who live in the rural areas (Mamdani, 2008; McCandless, 2011). More so, in some instances, the men abuse the income derived from the sale of this produce. This becomes a source of grievance for the wives and there are reported incidences where the aggrieved wives have committed suicide. Hence, as a result of this agitation, lack of land for agricultural activities may force them to migrate to urban areas where their chances of getting formal employment are very slim. Most of them end up engaging in informal income generation activities such as petty trading which may not give them enough income and a livelihood to live on in the comparatively more expensive urban environment (World Bank, 2006; Mitchell et al., 2009; Dekker and Kinsey, 2011).

In Zimbabwe, under the Model A2 resettlement programme where there is a lease to buy arrangement, the woman would be able to inherit the land directly from her husband under either the Administration of Estates (Amendment) Act (6 of 1997) or the Deceased Estates Succession Act, Chapter 6:02 depending on the type of marriage that she had with her husband (customary or civil) and provided there are title deeds to the land (Helliker 2008; Hungwe, 2011).

\section{Women Access to Land in Zimbabwe}

The current legal framework on women's access to land and other agrarian resources has several inequities. These range from outright discrimination to provisions that result in discrimination when applied to the reality of women's lives. With regard to freehold land, there is no direct discrimination against women. Women are free to purchase and own free hold land. However, the reality of women's lives is that most of them do not have the resources to purchase land for agricultural purposes. The Rukuni Commission (1994) found that only 2.3\% of large scale commercial farms were owned by women (GoZ, 1998; Chiweshe, 2012). In the resettlement areas, women are free to apply for land under Model A1 or Model A2. For Model A1, the interested women must apply through traditional leadership if they live in communal areas or through councillors if they live in other areas. Patriarchal tendencies have hindered women from applying for land in their own right with most of them preferring to let their husbands apply (Borras, 2005, Bond, 2008; Matondi, 2011). More so, this happens when the authorities that allocate land allocate it to men on the grounds that they are the customary heads of households. Moyo (2004) contends that women do not have direct access to the land and they actually access it through men. The role of traditional leadership that village heads, headmen and chiefs' need to be critically examined. Some traditional leaders have been known to oppose women's rights in general, particularly those that challenge patriarchy such as the Legal Age of Majority Act (which is now section 15 of the General Law Amendment Act, Chapter 8:07) (Chambati and Moyo, 2004). 


\section{Women Land use rights and Rural Development}

Secure rights to land and property for women are widely regarded as fundamental to ensuring effective and sustainable human and rural development. Rights to land and property include the right to own, use, access, control, transfer, exclude, inherit and otherwise make decisions about land and related resources. In this regard, secure rights to land are rights that are clearly defined, long-term, enforceable, appropriately transferable, and legally and socially legitimate (Moyo and Yeros, 2005; Zamchiya, 2011). For women, exercising these rights should not require consultation or approval beyond that required of men (McCandles, 2011). Land is one of the cornerstones of economic trajectory and rural development on which farmers, pastoralists and other communities base their livelihoods (Dzvimbo, Monga and Mazhizha, 2017). Most humanitarian agencies, NGOs and governments often concentrate on women's access to social services, training and education, and domestic violence, among others, despite women facing land related challenges in the aftermath of the conflict (Kindi, 2010; Odeny, 2013). Yet addressing all the other challenges is dependent on the security women have in access and use of land. As Cotula (2007) argued, land rights cut across a number of different sectors including displacement and return, human settlements, agriculture and livelihood, economic development, environmental issues, urban and rural planning, security, land mines, and justice and the rule of law. Land is a basis for shelter, food, economic activities, and is the most significant employer of women's labour in Sub-Saharan Africa (Kabonesa, 2002; Mashizha, Ncube, Monga and Dzvimbo, 2017). Rural poverty is strongly associated with poor access to land, either in the form of landlessness or because of insecure and contested land rights. Economic analysis has long recognized the importance of secure property rights for growth, and therefore for the poverty reduction which growth can bring. Increased land access for the poor can also bring direct benefits of poverty alleviation, not least by contributing directly to increased household food security (Moyo and Sukume, 2004). Equally, these issues are intimately connected with rural development policies and environmental outcomes (Cotula et al., 2004; Hungwe, 2011). Gender has become a critical issue in women's land rights due to the fact that there is direct relationship between accessing land resources, having secured land rights, achieving food security and overcoming poverty. Women produce more than $80 \%$ of the food in Africa, yet they own only 1\% of the land (Cotula et al., 2004; Zamchiya, 2011). Therefore, improving women's access to and control over land is crucial to socio-economic development of Africa.

\section{The nexus: Land use rights and Food security}

The dramatic rise in global food prices which had tremendous effects to countries of the Global South hampered the already limited ability of many people to buy food, highlighting the vulnerable state of food security and nutritional status for millions of people around the world (IFAD, 2010). When people lack secure and sustainable access to sufficient and nutritious food, hunger and malnutrition have profoundly negative impacts on their health and productivity. Given these high stakes and the recognition that food security will become an increasingly important issue in light of the growing world population, governments, policymakers, and other stakeholders in the international development community are paying greater attention to agricultural interventions that can help reduce global hunger and malnutrition (FA0, 2011; Dzvimbo, Monga and Mashizha, 2017). More so, secure rights to land are a critical, but often overlooked, factor in achieving household food security and improved nutritional status. Secure land rights refer to rights that are clearly defined, long-term, enforceable, appropriately transferrable and legally legitimate and are a catalyst to rural and infrastructural development. These rights can lead to increased household agricultural productivity and production by providing incentives to invest in improvements to the land, increasing opportunities to access financial services and government programs, and creating the space needed one without constant risk of losing land-for more optimal land use (Giovarelli and Wamalwa, 2011). 
Furthermore, increased agricultural productivity and production can enhance household food security and nutrition through two avenues: directly, through increased food production for consumption, and indirectly, through increased incomes permitting the purchase of more and better quality food.

In both ways, secure rights to land can help moderate the impact of food price volatility on poor rural households (UN, 2010). A growing body of evidence and discourse, from a variety of settings around the world, illustrates the positive relationship between land rights and food security and nutrition. A baseline survey of a land purchase program in Sanyati district in Zimbabwe, which gave beneficiaries plots of land of up to one hectare, found that beneficiary households experienced significantly higher levels of food security that is $70 \%$ of beneficiary households reported having two meals a day, compared to only $45-55 \%$ of non-beneficiary households (Murisa, 2010; Chiweshe, 2012). Hence, even secure rights to "micro plots" of land plots as small as one-tenth of an acre protect against household food insecurity and improve nutrition. They provide space for home gardens and for keeping poultry, livestock, or other animals. A variety of studies show that these micro plots produce a high percentage of the fruits and vegetables consumed by families (Mitchell et al., 2009).

\section{Women Empowerment and Food Security}

The relationship between secure land tenure and household food security is more pronounced when women have secure land rights and when they have secure property rights as well as the freedom they want, they gain improved status which leads to greater influence over household decisions. Furthermore, when women have direct control over assets like land and the income from those assets, they are more likely than men to spend the income on the next generation. Indeed, a World Bank report points out that the income and resources that women control wield disproportionately strong effects on health and nutrition outcomes generally (World Bank, 2007; Dekker and Kinsey, 2011). Women with land rights as is the case in most countries of the Global South generally have enhanced status and greater bargaining and decisionmaking power at home and in their communities (Katz and Chamorro, 2002; FAO, 2012). In Nepal, researchers found that women who own land are significantly and more likely to have the final say "I" in household decisions as in contrast in Sub Saharan Africa (Allendorf, 2007; IFAD, 2010). Women with secure rights to land also have greater influence over decisions regarding what types of crops to grow on that land and what type of animals to rear. Studies have shown that in some settings, men tend to plant crops with a high market value, whereas women tend to plant crops that can supplement a family's diet (Mitchell and Hanstad, 2004). Furthermore, when women own land, their food purchasing decisions are likely to benefit the household's food security and their children's nutritional status. A study carried out in Ghana showed that when women own a larger share of the household's farmland, families allocate a larger proportion of their household budget to food (Moyo, 2004; IFAD, 2010). Despite the evidence showing that women have a pivotal role in improving household food security and nutrition as well as being the pillar of the family's strength when they have secure land rights and also many women have only weak or unclear rights over the land they farm.

\section{Policy options: Challenges and Constraints}

As a result of colonial influences, individualization of land tenure, land market pressure and other factors, many customary laws and practices have eroded over time; the forms of solidarity that used to exist and that protected women from exclusion, have now decimated and vanished in many areas (Hungwe, 2011; Mkandawire, 2012). Even where statutory national laws recognize women's rights to land, housing and property, "traditional" values and stereo typing prevail amongst judges, police officers, local councillors and land officials. They often interpret statutory laws in what at present are understood to be "customary ways", as a 
result of which women are deprived of the rights they should enjoy under statutory law (Benschop, 2004). Overemphasis on privatization, individual freehold tenure and rigid planning and registration procedures that are costly, lengthy and often inaccessible to the (urban) poor deepens the gap between those who can and those who cannot afford (Benschop, 2004; Mitchell et al., 2009). An increasing number of countries have now recognized women's equal rights in their Constitution, thus complying with international human rights standards and obligations. However, there still are countries, such as Zimbabwe, Zambia, Lesotho and Kenya, where discrimination in customary and personal law matters (such as inheritance) is still permitted in their current Constitution. The necessity of a constitutional provision that prohibits discrimination, including in customary law and practice (as laid down in the Constitutions of Uganda, South Africa and Mozambique) cannot be overemphasized (Doss, 2006; Kindi, 2010).

There is need for clarification of which of the two sets of laws between customary and statutory law are used in land allocation (Dekker and Kinsey, 2011; FA0, 2011). The use of statutory law will help women if they are recognized as capable plot-holders in their own right with or without the involvement of men. Women A2 farmers can establish a national union and district-specific unions to represent them in credit and inputs negotiations, contract structuring and produce marketing. The government needs to finalize tenure agreements and both the men and the women in marriage need to be recognized as legal registrants while those women seeking land in their own right must be allowed to be the registrants of the land which they apply for. In many sub-Saharan African countries, the idea of women inheriting land is seen as a threat to the continuity of clan land Moyana, 2002; Human Rights Watch, 2004). Even in various matrilineal societies, such as in Malawi, Zambia, Mozambique and Tanzania, land market pressure and individual registration processes are threatening the continuity of inheritance systems that so far have protected women more. Religious laws usually entitle women to inherit, but the share of inheritance is invariably smaller, and there is an emphasis on access rather than ownership rights (Moyo and Yeros, 2005, Chiweshe, 2012). Without gender aware officials on bodies dealing with land allocation, inheritance and dispute settlement, a male bias among these officials will continue to stand in the way to women's enjoyment of their rights. Moreover, inclusion of women in decision-making and policy formulation processes, especially among vulnerable groups such as slum dwellers, and ethnic minorities is crucial.

\section{RECOMMENDATIONS AND CONCLUSION}

In order for land to play a key role in socio-economic growth and poverty alleviation, a functioning land administration system must support secure, easily transferable land rights and be capable of maintaining comprehensive, clear, accessible land records; creating mechanisms for the efficient and effective transfer of land for a reasonable fee; and providing accessible avenues for handling land disputes fairly, predictably, and in a timely fashion. Effective land administration requires women's participation at policy formulation and at level of implementation on an equal footing with men in order to ensure gender-equitable land tenure system. Hence meaningful representation is an important step towards helping women gain access to established rights. It is not just a matter of placing women in positions to add to numbers, but to ensure that their voices are heard. Women must be an integral part of the implementation of land reform programmes. Training community members as paralegals, topographers and conflict mediators can help build community skills and increase the probability that women's concerns will be addressed. Women's organizations can be effective tools in promoting local participation, building consensus and raising consciousness at all levels, especially as women are generally not well represented in decision-making bodies, and they are often instrumental in pressuring for government programmes to include women as 
equal participants. There is a need to develop land reform policies and tenurial structures that secure women's access to land and their control over the land they are allocated. This implies that governments must recognize, promote the land rights of women who are married, divorced, widowed or single and facilitate women's participation in the design of tenure systems because women's labour is a major contributor to agriculture hence their land rights matter for development

\section{References}

Abdulai, R.T. and Antwi, A. (2005). "Traditional Landholding Institutions and Individual Ownership of Land Rights in sub-Saharan Africa." World Review of Science, Technology and Sustainable Development, 2(3/4): 302-319.

Alexander, J. (2006). The Unsettled Land: State-Making and the Politics of Land in Zimbabwe 1893-2003, Harare: James Currey and Weaver Press.

Allendorf, K. (2007). Do Women's Land Rights Promote Empowerment and Child Health in Nepal?, WORLD DEVELOPMENT 35 (11).

Arrighi, G., Aschoff, N. and Scully, B., 2010, 'Accumulation by Dispossession and its Limits: The Southern Africa Paradigm Revisited', St Comp Int Dev, 45, 410-438.

Bernstein, H. (2012). 'Zimbabwe's Land Reform: Myths and Realities - by Ian Scoones, Nelson Marongwe, Blasio Mavedzenge, Jacob Mahenehene, Felix Murimbarimba and Chrispen Sukume', Journal of Agrarian Change, (12), 170-173.

Bond, P. (2008). 'Response to Lessons of Zimbabwe'. (http://links.org.au/node/815/9693) 8 June 2011.

Borras, S.M. Jr. (2005). 'Can redistributive reform be achieved via market-based land transfer schemes? Lessons and evidence from the Philippines', Journal of Development Studies, 41(1), 90-134.

Bryceson, D. (1996). 'Deagrarianization and rural employment in sub-Saharan Africa: A sectoral perspective', World Development, 24(1), 97-111.

Buka, F. (2002). A preliminary audit report of the Land Reform Programme. Unpublished report, Harare: Government of Zimbabwe.

Chambati, W. and Moyo, S. (2004). 'Land Reform and the Political Economy of Agricultural Labour', Harare: African Institute for Agrarian Studies. Mimeo.

Chiweshe, M. (2012). 'Farm level institutions in emergent communities in post fast track Zimbabwe: case of Mazowe district', PhD. Thesis, Grahamstown: Rhodes University

Cliffe, L., Alexander, J., Cousins, B. and Gaidzanwa, R. (2011). 'An overview of Fast Track Land Reform in Zimbabwe', editorial introduction, Journal of Peasant Studies, 38(5), 907-938.

Cotula, Lorenzo (ed.). (2007). Changes in "Customary" Land Tenure Systems in Africa. Great Britain:IIED.Retrievedon27-February-2010,from http://www.iied.org/pubs/pdfs/12537IIED.pdf.

Cousins, B., (2009). Potential and Pitfalls of Communal Land Tenure Reform: Experience in Africa and Implications for South Africa.

De Grassi, A. (2008).“Neo-patrimonialism” and Agricultural Development in Africa: Contributions and Limitations of a Contested Concept', African Studies Review, 51(3), 107-133.

Dekker, M. and Kinsey, B. (2011).'Contextualizing Zimbabwe's land reform: long-term observations from the first generation', Journal of Peasant Studies, 38 (5), 995-1019.

Doss, C. (2006). The Effects of Intra-household Property Ownership on Expenditure Patterns in Ghana, Journal of African Economies 15(1): 149-180.

Dzvimbo, M. A., Monga, M. \& Mashizha, T. M. (2017).The link between rural institutions and rural development: Reflections on smallholder farmers and donors in Zimbabwe. Journal of Humanities and Social Science, 22(6), 4653.

FAO (Food and Agriculture Organization). (2007). Good governance in land tenure and administration. Land Tenure Studies . Food and Agriculture Organization, Rome.

FAO. (2011). "The state of food and agriculture 2010-2011: Women in Agriculture: Closing the gender gap for development”. Rome: FAO. 
Giovarelli, R and Wamalwa, B. (2011). Issue Brief - Land Tenure, Property Rights, and Gender: Challenges and Approaches for Strengthening Women's Land Tenure and Property Rights, Washington: USAID.

GoZ. (1998). 'Land Reform and Resettlement Programme Phase II: A Policy Framework and Project Document', Harare: Government Printers.

Hanstad T. and R. Nielsen. (2009) “Land Tenure Reform in India." In One Billion Rising, edited by R. Prosterman, et al. Leiden: Leiden University Press.

Helliker, K. D. (2008), "Dancing on the Same Spot: NGOs”, in Moyo, S., Helliker, K. D and Murisa, T. (eds.), Contested Terrain: Land Reform and Civil Society in Contemporary Zimbabwe, Pietermaritzburg: S\&S Publishers.

Human Rights Watch (HRW). (2004). 'The politics of food assistance in Zimbabwe', A Human Rights Watch Briefing Paper, Human Rights Watch.

Hungwe, M. (2011). 'In Search of “Community” in Zimbabwe's Fast Track Resettlement Area of Mazowe District', PhD Thesis, Lund, Sweden: Lund University.

IFAD (International Fund for Agricultural Development). (2010). Improving access to land and tenure security. Corporate Land Policy. International Fund for Agricultural Development, Rome.

Kabonesa, K . (2005). “Gender Mainstreaming and Implications for Peace”, Gender and Peace Building in Africa.

Katz, E and Chamorro, J. (2002). Gender, Land Rights and the Household Economy in Rural Nicaragua and Honduras 11, paper prepared for the Regional Workshop on Land Issues in Latin America and the Caribbean, Paper prepared for USAID/BASIS CRSP. Madison, Wisconsin.

Kindi, F. I. (2010).Challenges and Opportunities for Women's Land Rights in the Post-Conflict Northern Uganda. MICROCON Research Working Paper 26, Brighton: MICROCON

Kinsey, B., Burger, K., and Gunning, J.M. (1998).Coping with drought in Zimbabwe: Survey evidence on responses of rural households to risk. World Development, 26 (1):89-110.

Logo, P.B. and Bikie, E., 2003. "Women and Land in Cameroon: Questioning Women"s Land Status and Claims for Change." In L. Muthoni Wanyeki (ed.): Women and Land in Africa: Culture, Religion and Realizing Women's Rights. South Africa: David Philip Publishers

Mafeje, A. (2003). 'The Agrarian Question, Access to Land and Peasant Responses in Sub-Saharan Africa, UNRISD Civil Society and Social Movements Programme Paper Number 6 May 2003, Geneva: United Nations Research Institute for Social Development.

Mamdani, M. (2008). 'Lessons of Zimbabwe', London Book Review.

Matondi, P., ed. (2011). Inside the political economy of redistributive land and agrarian reforms in Mazoe, Shamva and Mangwe districts in Zimbabwe, Harare: Ruzivo Trust.

McCandless, E. (2011) Polarisation and Transformation in Zimbabwe: Social Movements, Strategy Dilemmas and Change, Lanham: Lexington Books.

Mkandawire, T. (2012). Neo-patrimonialism and the political economy of economic performance in Africa: Critical reflections, London School of Economics.

Moyana, H.V. (2002). The political economy of land in Zimbabwe, Gweru: Mambo Press.

Moyo, S. (2004). 'The overall impact of the Fast Track Land Reform Programme', AIAS monograph, Harare: African Institute for Agrarian Studies.

Moyo, S. and Sukume, C. (2004). 'Farm Sizes, decongestion and land use: Implications of the Fast Track Land Redistribution Programme in Zimbabwe’, Harare: AIAS Mimeo.

Moyo, S. and Yeros, P. (2005). 'Introduction', in S. Moyo and P. Yeros, eds., Reclaiming the land: the resurgence of rural movements in Africa, Asia and Latin America, London: Zed Books.

Miggiano et al., (2010). Links between Land Tenure Security and Food Security.

Mitchell, R and Hanstad, T. (2004). Small Homegarden Plots and Sustainable Livelihoods for the Poor. Leiden, UP Press

Mitchell, R., Haynes, K., Hall, N., Choong, W. and Oven, K (2008) 'The role of children and youth in communicating disaster risk', Children, Youth and Environments 18(2), 2008

Mitchell, T., Tanner, T and Lussier, K., (2007), “We know what we need.!'South Asian women speak out on climate change adaptation, Action Aid International, London and the Institute of Development Studies (IDS). 
Murisa, T. (2010). 'Emerging forms of social organisation and agency in the newly resettled areas of Zimbabwe: the cases of Goromonzi and Zvimba districts', PhD. Thesis, Grahamstown: Rhodes University.

Richardson, C. (2005). 'The loss of property rights and the collapse of Zimbabwe', Cato Journal, 25, (2), 541-565.

Rosset, P. and Courville, M. (2006). Promised Land: Competing Visions of Agrarian Reform, Oakland, CA: Food First Books.

Odeny, M. (2013). Improving Access to Land and Strengthening Women's Land Rights in Africa. Paper presented at the World Bank Conference on Land and poverty, Washington, DC.

UN-HABITAT. (2002). Rights and Reality: Are women's equal rights to land, housing and property implemented in East Africa? 2002. http://www.unhabitat.org/tenure.

UN (United Nations). (2010). High Level Task Force on the Global Food Security Crisis Updated Comprehensive Framework for Action. New York, United Nations.

World Bank. (2003). Land Policies for Growth and Poverty Reduction), 79-98. Strengthening Land Tenure and Property Rights Land Law and Policy. Washington DC: The World Bank.

World Bank. (2009). Module 4: Gender Issues in Land Policy and Administration. Gender in Agriculture Source Book. World Bank, Washington.

World Bank. (2006). Agricultural Growth and Land Reform in Zimbabwe: Assessment and Recovery Options, Report No. 31699-ZW, Washington DC: World Bank.

Zamchiya, P. (2011). 'A synopsis of land and agrarian change in Chipinge District, Zimbabwe', Journal of Peasant Studies, 38 (5), 1093-1122. 